\title{
Ocular Surface Disease Signs and Symptoms of Glaucoma Patients and Their Relation to Glaucoma Medication in Finland
}

\author{
Minna Parkkari ( $\nabla$ minna.parkkari@tuni.fi ) \\ University of Tampere \\ Petri Purola \\ University of Tampere \\ Hannu Uusitalo \\ University of Tampere
}

Research Article

Keywords: Ocular surface disease, glaucoma, medication, preservative, dry eye sensation

Posted Date: September 2nd, 2021

DOI: https://doi.org/10.21203/rs.3.rs-845958/v1

License: (a) (i) This work is licensed under a Creative Commons Attribution 4.0 International License. Read Full License 


\section{Abstract}

Purpose: To evaluate the prevalence of ocular surface disease (OSD) signs and symptoms of glaucoma patients in relation to topical glaucoma treatment and to compare them to non-glaucomatous population.

Methods: A multicenter, cross-sectional study consisting of private ophthalmology clinic visits in southern Finland. Glaucoma patients had a diagnosis of primary open-angle glaucoma, pseudoexfoliation glaucoma, pigmentary glaucoma or treated ocular hypertension. Control patients had no prior or current use of glaucoma medication. Recorded parameters included OSD signs and symptoms, used glaucoma medications during the past 6 months, and the product name and type of used antiglaucoma drugs.

Results: Glaucoma patients ( $n=564)$ showed higher severity of OSD sign parameters excluding Schirmer's test, as well as increased dry eye sensation compared to controls $(n=51)$. Beta-blockers and preservative-free prostaglandins had the smallest effect on all parameters. The increasing number of active compounds and administered eye drops per day showed an association with increasing severity of OSD signs and symptoms.

Conclusion: Glaucoma patients show higher prevalence of OSD signs and dry eye sensation compared to non-glaucomatous population. The use of preserved glaucoma medication, as well as high number of active compounds and eye drops increase the severity of these parameters. There are significant differences between the types of glaucoma medication used, and therefore the selection of them is important especially in patients suffering from OSD.

\section{Introduction}

Glaucoma is the worldwide leading cause of irreversible visual impairment [1]. Globally, the number of people suffering from primary open-angle glaucoma (POAG) was expected to rise to 65.5 million by 2020 [2]. In Finland, the number of glaucoma patients is over 90000 , and it is expected to increase to 120000 by 2040 because of the ageing of the population [3-4].

Glaucoma is associated with ocular surface disease (OSD). They both are known co-morbidities in ageing populations, and several studies have investigated the prevalence and impact of this clinical issue [5-10]. These studies demonstrate that even $74 \%$ of the glaucoma patients suffer from the symptoms of dry eye, which is the most common form of OSD [11]. The presence of OSD can affect the quality of life of glaucoma patients [12-13]. It is further known that poor compliance to treatment can contribute to the progression of glaucoma and OSD [14].

Benzalkonium chloride (BAC) is the most used preservative in eye drops. It is known that BAC exerts toxic properties in the conjunctival and corneal epithelia [15-16]. Typical side effects of BAC include conjunctival hyperemia, lid redness, conjunctival and corneal fluorescein staining, as well as subjective sensations such as stinging, watering, photophobia, and burning [13]. The outcome of glaucoma surgery may also be affected negatively by the previous chronic use of preserved antiglaucoma eye drops [17-19]. Based on these findings, BAC can significantly contribute to the ocular surface problems and the overall success of treatment in glaucoma patients.

To obtain more information about the prevalence and severity of ocular signs and symptoms in outpatient patients in private practices and the role of number and type of glaucoma drugs, we investigated in this cross-sectional study the occurrence of symptoms and signs of OSD in glaucoma patient cohort and their relation to glaucoma medication. For comparison, we also included a control group not suffering from glaucoma.

\section{Materials And Methods}

\section{Patients}

This study was based on a multicenter, cross-sectional, single visit study performed in 2011. The data was obtained from patients attending private ophthalmologist clinics, enrolled in consecutive order. The study and all used methods were performed in accordance with the tenets of the Declaration of Helsinki, and the protocol was submitted to the Independent 
Ethics Committee of Tampere University Hospital and to the Finnish Medicines Agency (FIMEA) for approval (ETL Code R11015M). Written informed consent was obtained from all subjects prior to inclusion. The data was collected by 13 investigators in 27 centers in southern Finland. The amount of control patients to be enrolled was one among the first 10 glaucoma patients and after that always two control patients among the next 20 glaucoma patients. Glaucoma patients eligible for the study were aged 18 years or more and had a diagnosis of POAG, pseudoexfoliation glaucoma (ExG), pigmentary glaucoma (PG) or treated $\mathrm{OH}$. The eligible control patients were 40 years or older, were not suffering from glaucoma, and had no prior or current use of glaucoma medication. Subjects were excluded if they had eye surgery performed within the last 6 months, had known allergy, alcoholism, drug abuse or any other condition that could have influenced the studied parameters.

Patient demography (i.e. gender and age), relevant systemic diseases and other pertinent information were assessed. Detailed information about these parameters has been published elsewhere [20]. Ocular diagnoses were recorded separately for both eyes as none, $\mathrm{OH}, \mathrm{POAG}$, ExG or PG. If the patient had POAG, ExG or PG in one eye and $\mathrm{OH}$ or no diagnosis in the other, the patient was classified as a corresponding glaucoma patient. If the patient had ExG in the first eye and POAG in the other eye, the patient was determined as an ExG patient. Glaucoma medication(s) used during the past 6 months, the product name and type of used antiglaucoma drugs were recorded. The same variables were assessed in control patients except for the use of glaucoma medication.

\section{Ocular signs}

We assessed six different ocular signs: eyelid redness, conjunctival redness/hyperemia, corneal and conjunctival fluorescein staining, fluorescein tear break-up time (fBut), and tear secretion. Presence of eyelid redness was evaluated and severity graded from 0 (none), 1 (mild), 2 (moderate), or 3 (severe). Conjunctival redness/hyperemia was assessed by using reference photos (SILK Conjunctival Redness Grading) and a five point scale: 0 = none, $1=$ mild, $2=$ moderate, $3=$ severe, $4=$ very severe. fBut was measured by adding fluorescein dye to the eyes and the tear film was observed under the slit lamb. The time it took to form micelles i.e. dry spots to develop was recorded as the fBUT (in seconds). After fBut measurement, corneal and conjunctival fluorescein stainings were scored by using reference pictures (Oxford Grading scale). Corneal (score 0 to V) and conjunctival staining (score 0 to $X$ ) were analyzed separately. Tear secretion was measured with Schirmer I test (without anesthesia) by placing filter paper under the lower eyelid for five minutes. The amount of moisture was read from the test strip (in millimeters). Both eyes were tested at the same time.

The assessment of ocular signs was made individually for the right and left eyes of glaucoma and control patients. The worst eye values were recorded for further analyses. An overall signs score was calculated by summarizing all six ocular sign scores, with higher score indicating more severe overall status.

\section{Ocular symptoms}

Ocular symptoms were evaluated via a post-visit telephone call made by a single, independent study nurse. All questions were asked with a fixed protocol. Evaluated ocular symptoms included irritation/burning/stinging, itching, foreign body sensation, tearing, and dry eye sensation. Each symptom was scored as none (0), very mild (1), mild (2), moderate (3) or severe (4). Additionally, a summary score from all five symptoms was calculated, with higher score indicating more severe overall status.

\section{Statistical analyses}

All statistical analyses were performed using R software version 3.5.1 (R Core Team, Foundation for Statistical Computing, Vienna, Austria). Because the distribution of the data was skewed, non-parametric Mann-Whitney Utest was used for continuous variables. Spearman's rank correlation coefficient was used to assess the correlation between two continuous variables. A two-tailed $p$ value of $<0.05$ was selected to determine statistical significance.

\section{Results}

A total of 568 glaucoma patients and 51 controls were enrolled across 27 study centers. Four glaucoma patients were excluded from the data analysis because of incomplete or missing medication information or diagnosis. Therefore, background information and ocular signs data were evaluated from 564 glaucoma patients. Data on ocular symptoms was obtained from 
562 glaucoma patients. Background information and ocular data were evaluated from all 51 controls. The mean ages and gender distribution of the study population and glaucoma types are shown in Table 1.

Table 1

Ocular diagnosis, mean age and gender of glaucoma patients and controls

\begin{tabular}{|lllll|}
\hline & & $\mathbf{n}(\%)$ & Mean age & \% women \\
\hline Glaucoma patients & All & 564 & 70.2 & 67.9 \\
\cline { 2 - 5 } & Primary open-angle glaucoma & $451(80.0)$ & 69.4 & 66.7 \\
\cline { 2 - 4 } & Pseudoexfoliation glaucoma & $90(16.0)$ & 75.7 & 74.4 \\
\cline { 2 - 4 } & Pigmentary glaucoma & $12(2.1)$ & 61.2 & 66.7 \\
\hline Controls & Ocular hypertension & $11(1.9)$ & 66.3 & 63.6 \\
\hline
\end{tabular}

When compared to controls, glaucoma patients showed statistically significant worsening in all ocular sign parameters and overall signs score $(p<0.001$, Mann-Whitney Utest) except in Schirmer's test (Table 2a). When ocular symptoms were evaluated, glaucoma patients showed statistically significant increase in dry eye sensation $(p=0.040)$ and symptom sum $(p=$ 0.024) compared to controls (Table 2b). After age-adjustment, corneal fluorescein staining and fBUT showed no longer significant difference. On the contrary, itching appeared to show significant difference.

Table 2

a Ocular signs in glaucoma patients and controls

\begin{tabular}{|c|c|c|c|c|}
\hline Ocular sign & $\begin{array}{l}\text { Glaucoma } \\
\text { patients } n=564 \text {; } \\
\text { (SD) }\end{array}$ & $\begin{array}{l}\text { Controls } \\
n=51 ; \\
\text { (SD) }\end{array}$ & $\begin{array}{l}\text { Difference Glaucoma- } \\
\text { Control: Mann-Whitney, p }\end{array}$ & $\begin{array}{l}\text { Age- } \\
\text { adjusted } \\
\text { difference: } \\
\text { Mann- } \\
\text { Whitney, p }\end{array}$ \\
\hline Eyelid redness & $0.9(0.8)$ & $\begin{array}{l}0.04 \\
(0.2)\end{array}$ & $<0.001$ & $<0.001$ \\
\hline Conjunctival redness (SILK scale) & $1.9(0.8)$ & $1.2(0.8)$ & $<0.001$ & 0.006 \\
\hline Corneal fluorescein staining (Oxford scale) & $1.3(1.3)$ & $0.8(1.0)$ & 0.006 & 0.66 \\
\hline $\begin{array}{l}\text { Conjunctival fluorescein staining (Oxford } \\
\text { scale, combined nasal \& temporal) }\end{array}$ & $2.8(2.1)$ & $2.0(2.1)$ & 0.005 & $<0.001$ \\
\hline fBUT (seconds) & $5.2^{\mathrm{a}}(4.2)$ & $\begin{array}{l}7.3^{b} \\
(8.4)\end{array}$ & 0.008 & 0.31 \\
\hline Schirmer's test (millimeters) & $10.8(8.1)$ & $\begin{array}{l}11.9 \\
(8.1)\end{array}$ & 0.36 & 0.55 \\
\hline Overall signs score & $10.9(4.7)$ & $7.4(4.8)$ & $<0.001$ & 0.015 \\
\hline \multicolumn{5}{|l|}{$a_{n}=557^{b} n=48$} \\
\hline$S D$, standard deviation & & & & \\
\hline
\end{tabular}


Table 2

b Ocular symptoms in glaucoma patients and controls

\begin{tabular}{|lllll|}
\hline Ocular symptom & $\begin{array}{l}\text { Glaucoma patients } \\
\mathbf{n = 5 6 2}\end{array}$ & $\begin{array}{l}\text { Controls } \\
\mathbf{n = 5 1}\end{array}$ & $\begin{array}{l}\text { Difference Glaucoma-Control: } \\
\text { Mann-Whitney, } \mathbf{p}\end{array}$ & $\begin{array}{l}\text { Age-adjusted } \\
\text { difference: } \\
\text { Mann-Whitney, } \mathbf{p}\end{array}$ \\
\hline Irritation/burning/stinging & 0.69 & 0.57 & 0.41 & 0.22 \\
\hline Itching & 0.62 & 0.39 & 0.18 & $\mathbf{0 . 0 4 3}$ \\
\hline Foreign body sensation & 0.64 & 0.47 & 0.22 & 0.37 \\
\hline Tearing & 0.37 & 0.35 & 0.85 & 0.20 \\
\hline Dry eye sensation & 0.94 & 0.59 & $\mathbf{0 . 0 4 0}$ & $\mathbf{0 . 0 2 3}$ \\
\hline Symptom sum & 3.26 & 2.37 & $\mathbf{0 . 0 2 4}$ & $\mathbf{0 . 0 0 4}$ \\
\hline
\end{tabular}

Data on the ocular signs in different glaucoma medication types are shown in Table 3a. There was statistically significant worsening between different medication types in most of the observed signs when compared to controls. However, no significant difference was found in Schirmer's values. Beta-blockers and preservative-free prostaglandins had the least effect on these parameters, and they showed no significant effect on the overall sign score when compared to controls. Ocular symptoms in different glaucoma medication types are listed in Table 3b. Preserved prostaglandin, medication with three active compounds (fixed combination with beta-blocker and other (than prostaglandin) plus prostaglandin), and combinations with brimonidine showed statistically significant increase in symptom sum. In addition, combination of beta-blocker and prostaglandin, medication with three active compounds (fixed combination with beta-blocker and other (than prostaglandin) plus prostaglandin), and combinations with brimonidine showed statistically significant increase in dry eye sensation. 
Table 3

a Ocular signs related to glaucoma medication

\begin{tabular}{|c|c|c|c|c|c|c|c|c|}
\hline Medication & $\begin{array}{l}\text { Number } \\
\text { of } \\
\text { patients } \\
(\%)\end{array}$ & $\begin{array}{l}\text { Eyelid } \\
\text { redness }\end{array}$ & $\begin{array}{l}\text { Conjunctival } \\
\text { redness } \\
\text { (SILK scale) }\end{array}$ & $\begin{array}{l}\text { Corneal } \\
\text { fluorescein } \\
\text { staining } \\
\text { (Oxford } \\
\text { scale) }\end{array}$ & $\begin{array}{l}\text { Conjunctival } \\
\text { fluorescein } \\
\text { staining } \\
\text { (Oxford } \\
\text { scale, } \\
\text { combined } \\
\text { nasal \& } \\
\text { temporal) }\end{array}$ & $\begin{array}{l}\text { fBUT } \\
\text { (seconds) }{ }^{a}\end{array}$ & $\begin{array}{l}\text { Schirmer's } \\
\text { test } \\
\text { (millimeters) }\end{array}$ & $\begin{array}{l}\text { Overall } \\
\text { signs } \\
\text { score }\end{array}$ \\
\hline $\begin{array}{l}\text { Prostaglandin, } \\
\text { all }\end{array}$ & $\begin{array}{l}204 \\
(36.2)\end{array}$ & 0.8 *** & 1.8 *** & 0.9 & 2.5 & 6.3 & 12.4 & 9.9 ** \\
\hline $\begin{array}{l}\text { Preserved } \\
\text { prostaglandin }\end{array}$ & $\begin{array}{l}160 \\
(28.4)\end{array}$ & $0.8 * * *$ & $1.9 * * *$ & 1.0 & 2.4 & 5.9 & 12.1 & $\begin{array}{l}10.1 \\
* \star *\end{array}$ \\
\hline $\begin{array}{l}\text { Preservative- } \\
\text { free } \\
\text { prostaglandin }\end{array}$ & $44(7.8)$ & $0.8 * * *$ & 1.6 * & 0.8 & 2.8 * & 7.5 & 13.4 & 9.4 \\
\hline $\begin{array}{l}\text { Beta-blocker } \\
\text { and } \\
\text { prostaglandin } \\
\text { fixed-dose } \\
\text { combination }\end{array}$ & $\begin{array}{l}154 \\
(27.3)\end{array}$ & $1.0 * * *$ & $2.0 * \star \star$ & $1.5 * \star *$ & 2.6 & 4.9 * & 12.5 & 11.2 \\
\hline $\begin{array}{l}\text { Beta-blocker } \\
\text { and other } \\
\text { (than } \\
\text { prostaglandin) } \\
\text { fixed-dose } \\
\text { combination } \\
\text { plus } \\
\text { prostaglandin }\end{array}$ & $\begin{array}{l}58 \\
(10.3)\end{array}$ & $1.3 * * *$ & $2.1 * \star \star$ & 1.2 * & 3.4 ** & 5.3 & 12.1 & ${ }_{\star \star \star \star}^{12.0}$ \\
\hline $\begin{array}{l}\text { Beta-blocker } \\
\text { and } \\
\text { prostaglandin } \\
\text { fixed-dose } \\
\text { combination } \\
\text { plus carbonic } \\
\text { anhydrase } \\
\text { inhibitor }\end{array}$ & $37(6.6)$ & 1.1 *** & $2.0 * * *$ & $2.3 * * *$ & $3.4 * \star *$ & 3.2 ** & 14.0 & $\begin{array}{l}13.4 \\
\star \star \star\end{array}$ \\
\hline Beta-blocker & $34(6.0)$ & 0.2 * & 1.4 & 1.1 & 2.7 & 6.6 & 12.0 & 8.8 \\
\hline $\begin{array}{l}\text { Beta-blocker } \\
\text { and other } \\
\text { (than } \\
\text { prostaglandin) } \\
\text { fixed-dose } \\
\text { combination }\end{array}$ & $25(4.4)$ & 0.4 ** & $1.6 * * \star$ & 1.4 * & 3.3 ** & 6.5 & 10.4 & 10.4 ** \\
\hline $\begin{array}{l}\text { Prostaglandin } \\
\text { plus carbonic } \\
\text { anhydrase } \\
\text { inhibitor }\end{array}$ & $16(2.8)$ & $1.2 * \star *$ & $2.2 * \star \star$ & 1.6 * & 2.5 & 5.4 & 14.7 & 11.7 * \\
\hline
\end{tabular}

\footnotetext{
${ }^{a} n=557$

${ }^{b} n=48$
}

*Denotes statistical significance (Mann-Whitney) compared to controls with $p<0.05$

**Denotes statistical significance compared to controls with $p<0.01$

***Denotes statistical significance compared to controls with $p<0.001$ 


\begin{tabular}{|c|c|c|c|c|c|c|c|c|}
\hline Medication & $\begin{array}{l}\text { Number } \\
\text { of } \\
\text { patients } \\
(\%)\end{array}$ & $\begin{array}{l}\text { Eyelid } \\
\text { redness }\end{array}$ & $\begin{array}{l}\text { Conjunctival } \\
\text { redness } \\
\text { (SILK scale) }\end{array}$ & $\begin{array}{l}\text { Corneal } \\
\text { fluorescein } \\
\text { staining } \\
\text { (Oxford } \\
\text { scale) }\end{array}$ & $\begin{array}{l}\text { Conjunctival } \\
\text { fluorescein } \\
\text { staining } \\
\text { (Oxford } \\
\text { scale, } \\
\text { combined } \\
\text { nasal \& } \\
\text { temporal) }\end{array}$ & $\begin{array}{l}\text { fBUT } \\
\text { (seconds) }^{a}\end{array}$ & $\begin{array}{l}\text { Schirmer's } \\
\text { test } \\
\text { (millimeters) }\end{array}$ & $\begin{array}{l}\text { Overall } \\
\text { signs } \\
\text { score }\end{array}$ \\
\hline $\begin{array}{l}\text { Beta-blocker } \\
\text { and } \\
\text { prostaglandin }\end{array}$ & $14(3.9)$ & $0.7 * \star \star$ & 1.6 * & 0.6 & 2.6 & 8.3 & 9.0 & 9.3 \\
\hline $\begin{array}{l}\text { Combinations } \\
\text { with } \\
\text { brimonidine }\end{array}$ & $22(2.5)$ & 1.4 *** & $2.8 * \star \star$ & $2.3 * \star *$ & 3.7 ** & 2.9 * & 11.9 & 15.1 \\
\hline Total & 564 & & & & & & & \\
\hline Controls & 51 & 0.04 & 1.2 & 0.8 & 2.0 & $7.3^{b}$ & 11.9 & 7.4 \\
\hline \multicolumn{9}{|l|}{$a_{n}=557$} \\
\hline \multicolumn{9}{|l|}{${ }^{b} n=48$} \\
\hline \multicolumn{9}{|c|}{ *Denotes statistical significance (Mann-Whitney) compared to controls with $p<0.05$} \\
\hline \multicolumn{9}{|c|}{${ }^{\star *}$ Denotes statistical significance compared to controls with $p<0.01$} \\
\hline \multicolumn{9}{|c|}{$\star * \star$ Denotes statistical significance compared to controls with $p<0.001$} \\
\hline
\end{tabular}


Table 3

b Ocular symptoms related glaucoma medication

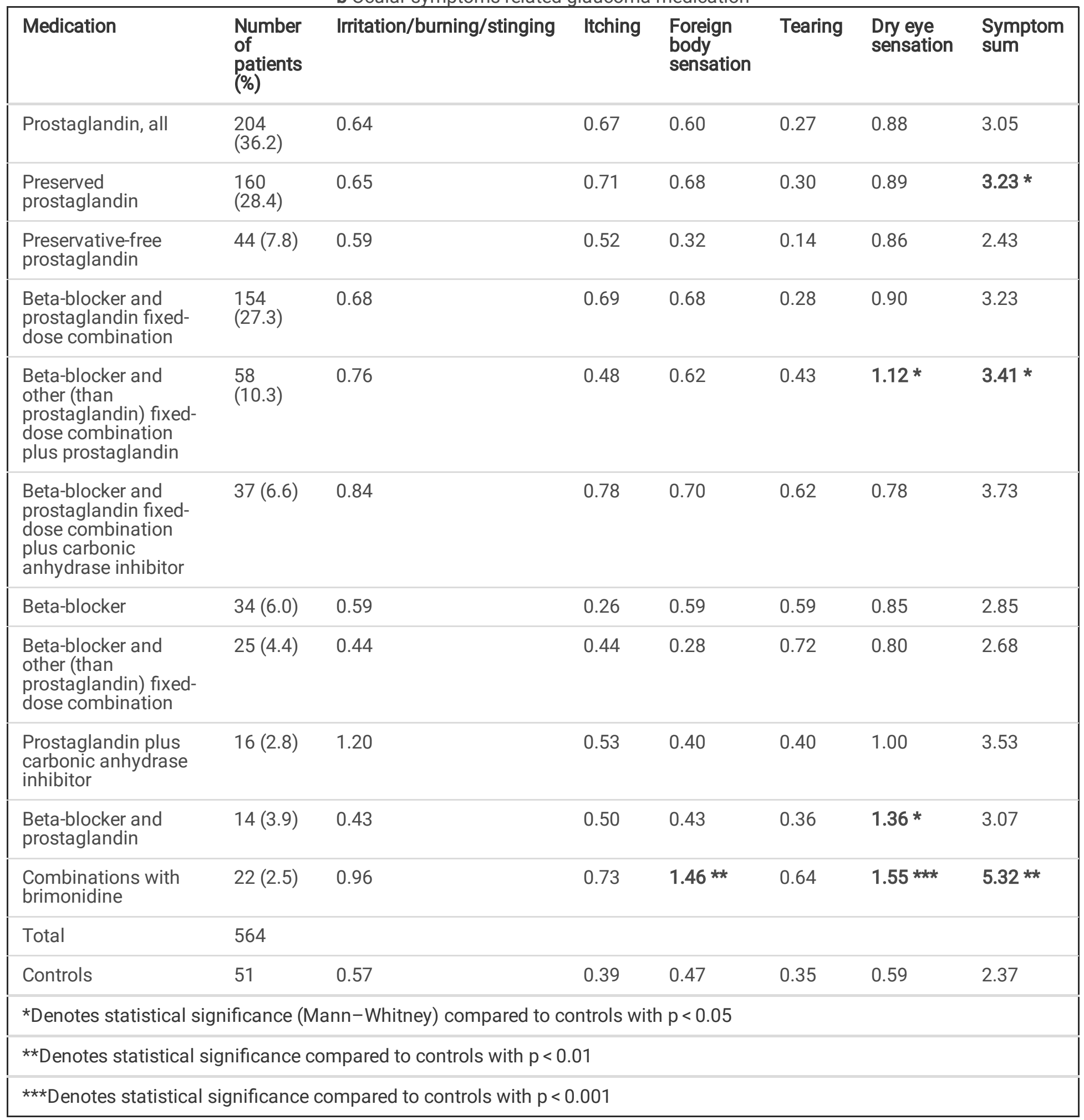

The relation of the number of used active compounds in glaucoma medication and ocular signs and symptoms are shown in Tables $4 \mathrm{a}$ and $4 \mathrm{~b}$. For the majority of the glaucoma patients (79\%), the glaucoma treatment consisted of one or two active compounds. As the number of active compounds increased, all subtypes of ocular signs worsened except Schirmer`s test. For symptoms, foreign body sensation, dry eye sensation, and symptom sum increased along with the increased number of active compounds. In Figs. $1 \mathrm{a}$ and $1 \mathrm{~b}$ are shown the overall signs score and the symptom sum with $95 \%$ confidence intervals according to the number of active compounds. There was a weak correlation $(r=0.27)$ between the increasing number of active compounds and the overall signs score. 
Table 4

a Ocular signs related to number of active compounds in glaucoma medication

\begin{tabular}{|c|c|c|c|c|c|c|c|c|}
\hline $\begin{array}{l}\text { Number of } \\
\text { active } \\
\text { compounds }\end{array}$ & $\begin{array}{l}\text { Number } \\
\text { of } \\
\text { patients } \\
(\%)\end{array}$ & $\begin{array}{l}\text { Eyelid } \\
\text { redness }\end{array}$ & $\begin{array}{l}\text { Conjunctival } \\
\text { redness } \\
\text { (SILK scale) }\end{array}$ & $\begin{array}{l}\text { Corneal } \\
\text { fluorescein } \\
\text { staining } \\
\text { (Oxford } \\
\text { scale) }\end{array}$ & $\begin{array}{l}\text { Conjunctival } \\
\text { fluorescein } \\
\text { staining } \\
\text { (Oxford scale, } \\
\text { combined } \\
\text { nasal \& } \\
\text { temporal) }\end{array}$ & $\begin{array}{l}\text { fBUT } \\
\text { (seconds) }\end{array}$ & $\begin{array}{l}\text { Schirmer's } \\
\text { test } \\
\text { (millimeters) }\end{array}$ & $\begin{array}{l}\text { Overall } \\
\text { signs } \\
\text { score }\end{array}$ \\
\hline 1 & $\begin{array}{l}241 \\
(42.7)\end{array}$ & 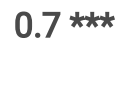 & 1.8 *** & 0.95 & 2.5 & 6.3 & 12.3 & 9.8 ** \\
\hline 2 & $\begin{array}{l}207 \\
(36.7)\end{array}$ & $0.9 * \star *$ & 1.9 *** & 1.3 ** & 2.7 * & 5.3 & 12.2 & 10.9 \\
\hline 3 & $\begin{array}{l}102 \\
(18.1)\end{array}$ & 1.2 *** & $2.1 * \star *$ & $1.7 * \star *$ & $3.4 * \star *$ & 4.3 ** & 12.6 & 12.8 \\
\hline $4-5$ & $14(2.5)$ & $1.6 * \star *$ & $3.1 * \star *$ & $2.8 * \star \star$ & $4.6 * \star *$ & 2.6 ** & 12.6 & 17.0 \\
\hline Total & 564 & & & & & & & \\
\hline 0 (controls) & 51 & 0.04 & 1.2 & 0.8 & 2.0 & $7.3^{\mathrm{b}}$ & 11.9 & 7.4 \\
\hline \multicolumn{9}{|l|}{$a_{n}=557$} \\
\hline \multicolumn{9}{|l|}{$b_{n}=48$} \\
\hline \multicolumn{9}{|c|}{ *Denotes statistical significance (Mann-Whitney) compared to controls with $p<0.05$} \\
\hline \multicolumn{9}{|c|}{ **Denotes statistical significance compared to controls with $p<0.01$} \\
\hline \multicolumn{9}{|c|}{$* * *$ Denotes statistical significance compared to controls with $p<0.001$} \\
\hline
\end{tabular}

Table 4

b Ocular symptoms related to number of active compounds in glaucoma medication

\begin{tabular}{|c|c|c|c|c|c|c|c|}
\hline $\begin{array}{l}\text { Number of } \\
\text { active } \\
\text { compounds }\end{array}$ & $\begin{array}{l}\text { Number of } \\
\text { patients (\%) }\end{array}$ & Irritation/burning/stinging & Itching & $\begin{array}{l}\text { Foreign } \\
\text { body } \\
\text { sensation }\end{array}$ & Tearing & $\begin{array}{l}\text { Dry eye } \\
\text { sensation }\end{array}$ & $\begin{array}{l}\text { Symptom } \\
\text { sum }\end{array}$ \\
\hline 1 & $241(42.7)$ & 0.63 & 0.61 & 0.60 & 0.32 & 0.88 & 3.04 \\
\hline 2 & $207(36.7)$ & 0.69 & 0.65 & 0.60 & 0.36 & 0.94 & 3.23 * \\
\hline 3 & $102(18.1)$ & 0.75 & 0.59 & 0.67 & 0.52 & $1.00 *$ & 3.52 * \\
\hline $4-5$ & $14(2.5)$ & 1.14 & 0.57 & 1.64 ** & 0.36 & 1.64 ** & 5.36 ** \\
\hline Total & 564 & & & & & & \\
\hline 0 (controls) & 51 & 0.57 & 0.39 & 0.47 & 0.35 & 0.59 & 2.37 \\
\hline \multicolumn{8}{|c|}{ *Denotes statistical significance (Mann-Whitney) compared to controls with $p<0.05$} \\
\hline \multicolumn{8}{|c|}{$\star \star$ Denotes statistical significance compared to controls with $p<0.01$} \\
\hline
\end{tabular}

Tables $5 \mathrm{a}$ and $5 \mathrm{~b}$ represent the ocular signs and symptoms related to the number of drops administered daily among the glaucoma patients. A majority of the glaucoma patients (67\%) instilled 1-2 glaucoma drops per day. All observed signs values worsened along with the increasing number of drops except the values of Schirmer's test. Foreign body sensation, dry eye sensation, and symptom sum increased alongside with the number of drops. The relation of the number of drops and the overall 
signs score and the symptom sum is shown in Figs. $2 a$ and $2 b$. There was a weak correlation $(r=0.15)$ between the increasing number of drops and the overall signs score.

Table 5

a Ocular signs related to number of administered eye drops per day among glaucoma patients

\begin{tabular}{|c|c|c|c|c|c|c|c|c|}
\hline $\begin{array}{l}\text { Number } \\
\text { of drops }\end{array}$ & $\begin{array}{l}\text { Number } \\
\text { of } \\
\text { patients } \\
(\%)\end{array}$ & $\begin{array}{l}\text { Eyelid } \\
\text { redness }\end{array}$ & $\begin{array}{l}\text { Conjunctival } \\
\text { redness } \\
\text { (SILK scale) }\end{array}$ & $\begin{array}{l}\text { Corneal } \\
\text { fluorescein } \\
\text { staining } \\
\text { (Oxford } \\
\text { scale) }\end{array}$ & $\begin{array}{l}\text { Conjunctival } \\
\text { fluorescein } \\
\text { staining (Oxford } \\
\text { scale, combined } \\
\text { nasal \& } \\
\text { temporal) }\end{array}$ & $\begin{array}{l}\text { fBUT } \\
\text { (seconds) }^{a}\end{array}$ & $\begin{array}{l}\text { Schirmer's } \\
\text { test } \\
\text { (millimeters) }\end{array}$ & $\begin{array}{l}\text { Overall } \\
\text { signs } \\
\text { score }\end{array}$ \\
\hline $1-2$ & $\begin{array}{l}377 \\
(66.9)\end{array}$ & $0.9 * \star *$ & $1.9 * \star *$ & 1.2 * & 2.5 & 5.7 & 12.4 & 10.4 \\
\hline $3-4$ & $\begin{array}{l}70 \\
(12.4)\end{array}$ & $0.7 * \star \star$ & $1.8 * \star *$ & 1.2 & 3.1 ** & 6.2 & 11.4 & 10.6 \\
\hline $5-6$ & $\begin{array}{l}100 \\
(17.7)\end{array}$ & $1.2 * * *$ & $2.0 * * *$ & $1.5 * * *$ & $3.2 * \star *$ & 4.9 & 12.6 & 12.0 \\
\hline $7-12$ & $17(3.0)$ & $1.6 * * *$ & $2.8 * \star \star$ & $2.5 * * *$ & 4.1 ** & $2.4 * \star \star$ & 11.4 & $\underset{* \star \star}{16.4}$ \\
\hline Total & 564 & & & & & & & \\
\hline $\begin{array}{l}0 \\
\text { (controls) }\end{array}$ & 51 & 0.04 & 1.2 & 0.8 & 2.0 & $7.3^{b}$ & 11.9 & 7.4 \\
\hline \multicolumn{9}{|l|}{$a_{n}=557$} \\
\hline \multicolumn{9}{|l|}{${ }^{b} n=48$} \\
\hline \multicolumn{9}{|c|}{ *Denotes statistical significance (Mann-Whitney) compared to controls with $p<0.05$} \\
\hline \multicolumn{9}{|c|}{$\star \star$ Denotes statistical significance compared to controls with $p<0.01$} \\
\hline$\star \star \star$ Denote & atistical & nificanc & ompared to & trols with $p$ & 001 & & & \\
\hline
\end{tabular}

Table 5

b Ocular symptoms related to number of administered eye drops per day among glaucoma patients

\begin{tabular}{|c|c|c|c|c|c|c|c|}
\hline $\begin{array}{l}\text { Number of } \\
\text { drops }\end{array}$ & $\begin{array}{l}\text { Number of } \\
\text { patients (\%) }\end{array}$ & Irritation/burning/stinging & Itching & $\begin{array}{l}\text { Foreign body } \\
\text { sensation }\end{array}$ & Tearing & $\begin{array}{l}\text { Dry eye } \\
\text { sensation }\end{array}$ & $\begin{array}{l}\text { Symptom } \\
\text { sum }\end{array}$ \\
\hline $1-2$ & $377(66.9)$ & 0.64 & 0.64 & 0.62 & 0.30 & 0.88 & 3.08 \\
\hline $3-4$ & $70(12.4)$ & 0.77 & 0.61 & 0.49 & 0.54 & 0.94 & 3.36 * \\
\hline $5-6$ & $100(17.7)$ & 0.78 & 0.56 & 0.70 & 0.49 & 1.10 ** & 3.63 * \\
\hline $7-12$ & $17(3.0)$ & 0.82 & 0.53 & 1.29 * & 0.53 & 1.47 ** & $4.65 *$ \\
\hline Total & 564 & & & & & & \\
\hline 0 (controls) & 51 & 0.57 & 0.39 & 0.47 & 0.35 & 0.59 & 2.37 \\
\hline \multicolumn{8}{|c|}{ *Denotes statistical significance (Mann-Whitney) compared to controls with $p<0.05$} \\
\hline \multicolumn{8}{|c|}{$\star \star$ Denotes statistical significance compared to controls with $p<0.01$} \\
\hline$\star \star \star$ Denotes & istical sign & ompared to controls wi & 0.001 & & & & \\
\hline
\end{tabular}

\section{Discussion}


The results in our study demonstrate that the glaucomatous population treated with topical medication show significantly increased OSD signs and symptoms compared to non-glaucomatous population. These findings are consistent with previous studies that have showed association between glaucoma medication and OSD [8, 21-22]. Furthermore, a long-term exposure to glaucoma eye drops has been associated with changes in the ocular surface, conjunctiva, and trabecular meshwork [23-25]. During the recent years, special attention has been paid on the role of preservatives in glaucoma eye drops. Preserved topical glaucoma medication has been shown to cause OSD signs and symptoms, whereas preservative-free medications have showed significantly less ocular toxicity $[7,9,13,23,26]$. In the presence study, we found similar relation to preservative-free compounds.

BAC is the most used preservative in ocular drugs. It is effectively penetrating to the eye tissues and has long-term effects on them [16]. In addition to its effects on the ocular surface that causes ocular signs and symptoms, the use of BAC-containing drugs has been directly linked to the failure of glaucoma surgery [17-19]. A recent glaucoma guideline recommends the use of preservative-free medication in patients suffering from OSD [27].

According to glaucoma guidelines, monotherapy is the preferred type of medication in glaucoma care. In our study, $42.7 \%$ of all glaucoma patients were using only one active compound. More than half of the glaucoma patients were using combined medications with multiple active compounds and daily eye drops. Furthermore, European Glaucoma Society Guidelines recommend the maximum use of three active compounds and three-four eye drops per day [27]. In our study, $2.5 \%$ of the glaucoma patients had more than three active compounds in their medication and $20.7 \%$ used more than four eye drops per day. Similar reports have been shown previously [28-29]. In this respect, it is important to recognize that the increasing number of active compounds and administered eye drops per day is associated with increasing severity of OSD signs, as shown in this study.

Most of the glaucoma patients in this study suffered from the symptoms of OSD. This was most significant in those who were medicated with three active compounds (fixed combination with beta-blocker and other (than prostaglandin) plus prostaglandin) or combinations with brimonidine. The symptoms of dry eye correlated with the increasing number of active compounds and/or eye drops of the used medication.

The strengths of this study include the robust, prospective nature of it. All data was obtained collectively from private clinics outpatients. Study subjects that were willing to participate in the study were enrolled consecutively at each center avoiding selection bias. As the study was multicenter-based with a large number of patients, the study represents well private clinics, where a significant proportion of glaucoma patients are treated by private ophthalmologists in Finland. To our knowledge, this is the first study to do so with standardized methods that include reference images for the OSD signs and a single, independent study nurse with a fixed protocol regarding the OSD symptom questionnaire.

Our study has also some limitations. Although this study was prospective, it was blinded only for recording the OSD symptoms by a single, independent study nurse. The study was cross-sectional and assessed only patients attending private ophthalmologist clinics in Finland. Therefore, even though these results can represent outpatient patient in general, they cannot be directly compared to those obtained from public eye hospitals.

Our results demonstrate that multi-therapy is common among glaucoma outpatients. Also, the prevalence of OSD signs and symptoms among these patients is related to the number of active compounds and administered eye drops per day. There are significant differences between glaucoma medications. Beta-blockers and preservative-free prostaglandin show the least effect on both ocular signs and symptoms. Therefore, BAC likely contributes to the ocular surface problems. These findings suggest that the use of preservative-free glaucoma medication is highly recommended. Special attention should be paid on patients having OSD signs and symptoms on what type of medicine is prescript, and in case of multi-therapy, to select laser or surgical treatment instead of increasing topical medication.

\section{Declarations}

\section{Funding}

Page $11 / 15$ 
This work was supported by Santen Oy, Finland. The funding source did not influence the study design, data collection, analysis, interpretation, or writing of the publication. The corresponding author had full access to all the data in the study and had responsibility for the decision to submit the paper for publication.

\section{Conflicts of interest}

The authors declare that they have no conflict of interest.

\section{Ethics approval}

The study protocol was approved by the Independent Ethics Committee of Tampere University Hospital and the Finnish Medicines Agency (ETL R11015M, date 9.2.2011).

\section{Consent to participate}

Written informed consent was obtained from all subjects prior to inclusion.

\section{Consent for publication}

All authors have accepted the publication of the paper.

\section{Availability of data and material}

Not applicable

\section{Code availability}

Not applicable

\section{Contributors}

Research design was by MP and HU. HU managed the project. Data acquisition was by MP. Data was analyzed by PP and MP. All authors contributed to the interpretation of data. MP and PP prepared the first draft and finalized the manuscript based on comments from all authors.

\section{References}

1. World Health Organization (2014) Visual impairment and blindness. Fact Sheet No 282.

2. Kapetenakis VV, Chan MP, Foster PJ, Cook DG, Owen CG, Rudnika AR (2016) Global variations and time trends in the prevalence of primary open angle glaucoma (POAG): a systemic review and meta-analysis. Ophthalmol 100:86-93.

3. Uusitalo HA, Ojamo M (2015) NVR 30 v. Näkökulmia suomalaiseen näkemiseen. Näkövammarekisterin julkaisusarja, The Social Insurance Institution of Finland 1/2015 IDDN: 1237-8984.

4. www.kela.fi (2011) Kela statistics. Helsinki: The Social Insurance Institution of Finland.

5. Baudouin C, Pisella PJ, Fillacier K, Goldschild M, Becquet F, Madga J, Be`chetoille A (1999) Ocular surface inflammatory changes induced by topical antiglaucoma drugs. Ophthalmol 106:556-563.

6. Nordmann JP, Auzanneau N, Ricard Se'verine, Berdeaux G (2003) Vision related quality of life and topical glaucoma treatment side effects. Health Qual Life Outcomes 1:75.

7. Jaenen N, Baudouin C, Pouliquen P, Manni G, Figueiredo A, Zeyen T (2007) Ocular symptoms and signs with preserved and preservative-free glaucoma medications. Eur J Ophthalmol 17:341-349.

8. Leung W, Medeiros A, Weinreb N (2008) Prevalence of ocular surface disease in glaucoma patients. Journal of Glaucoma 17:350-355. 
9. Uusitalo H, Egorov E, Kaarniranta K, Astakhov Y, Ropo A (2016) Benefits of switching from latanoprost to preservative-free tafluprost eye drops: a meta-analysis of two Phase Illb clinical trials. Clin Ophthalmol 10:445-454.

10. Pe'rez-Bartolome'F, Marti $\neq z-$ de - la - CasaJ, Arriola - Villalobos P, Fernandez-Pérez C, Polo V, Feijoo`J (2017) Ocular surface disease in patients under topical treatment for glaucoma. Eur J Ophthalmol 8:694-704.

11. Boso A, Gasperi E, Fernandes L, Costa V, Alves M (2020) Impact of ocular surface disease treatment in patients with glaucoma. Clin Ophthalmol 14:103-111.

12. Rossi GC, Tinelli C, Pasinetti GM, Milano G, Bianchi PE (2009) Dry eye syndrome-related quality of life in glaucoma patients. Eur J Ophthalmol 19:572-579.

13. Lemij H, Hoevenaars J, Windt C, Baudouin C (2015) Patient satisfaction with glaucoma therapy: reality or myth? Clin Ophthalmol 15:785-793.

14. Kotecha A, Fernandes S, Bunce C, Franks WA (2012) Avoidable sight loss from glaucoma: is it unavoidable? $\mathrm{Br} \mathrm{J}$ Ophthalmol 96:816-20.

15. Liang H, Pauly A, Riancho L, Baudouin C, Brignole-Baudouin F (2011) Toxicological evaluation of preservative-containing and preservative-free topical prostaglandin analoques on a three-dimensional-reconstituted corneal epithelium system. $\mathrm{Br} \mathrm{J}$ Ophthalmol 95:869-875.

16. Pellinen P, Huhtala A, Tolonen A, Lokkila J, Mäenpää J, Uusitalo H (2012) The cytotoxic effects of preserved and preservative-free prostaglandin analogs on human corneal and conjunctival epithelium in vitro and the distribution of benzalkonium chloride homologs in ocular surface tissue in vivo. Curr Eye Research 37:145-154.

17. Broadway DC, Grierson I, O’Brien C, Hitchings RA (1994) Adverse effects of topical antiglaucoma medication. II. The outcome of filtration surgery. Arch Ophthalmol 112:1446-1454.

18. Helin M, Rönkkö S, Puustjärvi T, Teräsvirta M, Ollikainen M, Uusitalo H (2011) Conjunctival inflammatory cells and their predictive role for deep sclerectomy in primary open-angle glaucoma and exfoliation glaucoma. Journal of Glaucoma 20:172-178.

19. Boimer C, Birt C (2013) Preservative exposure and surgical outcomes in glaucoma patients: The PESO study. Journal of Glaucoma 22:730-735.

20. Parkkari M, Taipale J, Uusitalo H (2019) Comparing glaucoma medications and general demographics in a sample of glaucoma patients treated in private practice with nationwide registry data in Finland. Acta Ophthalmol doi:

10.1111/aos.14338. Epub ahead of print. PMID: 31885212.

21. Mathews PM, Ramulu PY, Friedman DS, Utine CA, Akpek EK (2013) Evaluation of ocular surface disease in patients with glaucoma. Ophthalmology 120:2241-2248.

22. Garcia-Feijoo J, Sampaolesi JR (2012) A multicenter evaluation of ocular surface disease prevalence in patients with glaucoma. Clin Ophthalmol 6:441-446.

23. Pisella PJ, Pouliquen P, Baudouin C (2002) Prevalence of ocular symptoms and signs with preserved and preservative free glaucoma medication. Br J Ophthalmol 86:418-423.

24. Baudouin C, Hamard P, Liang $\mathrm{H}$ et al (2004) Conjunctival epithelial cell expression of interleukins and inflammatory markers in glaucoma patients treated over the long term. Ophthalmology 111:2186-2192.

25. Baudouin C (2009) The ocular surface in glaucoma. Cornea 28:S14-S19.

26. Rossi G, Scudeller L, Lumini C et al (2019) An in vivo confocal, prospective, masked, 36 months study on glaucoma patients medically treated with preservative-free or preserved monotherapy. Scientific reports 9:4282.

27. European Glaucoma Society (2020) Terminology and Guidelines for Glaucoma. 5th ed. Savona, Italy: Editrice Dogma Srl.

28. Kass MA, Heuer DK, Higginbotham EJ et al (2002) The Ocular Hypertension Treatment Study: a randomized trial determines that topical ocular hypotensive medication delays or prevents the onset of primary open-angle glaucoma. Arch Ophthalmol 120:701-713.

29. Nordstrom BL, Friedman DS, Mozaffari E, Quigley HA, Walker AM (2005) Persistence and adherence with topical glaucoma therapy. Am J Ophthalmol 140:598-606.

Page 13/15 


\section{Figures}

a

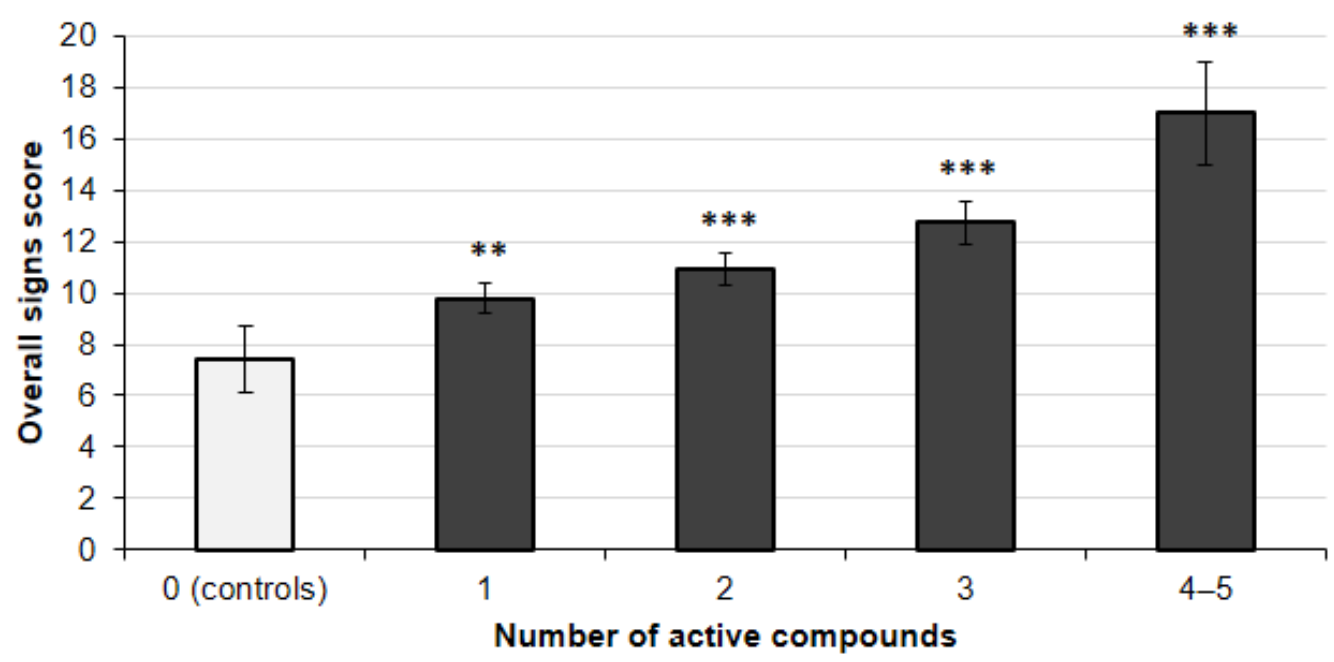

b

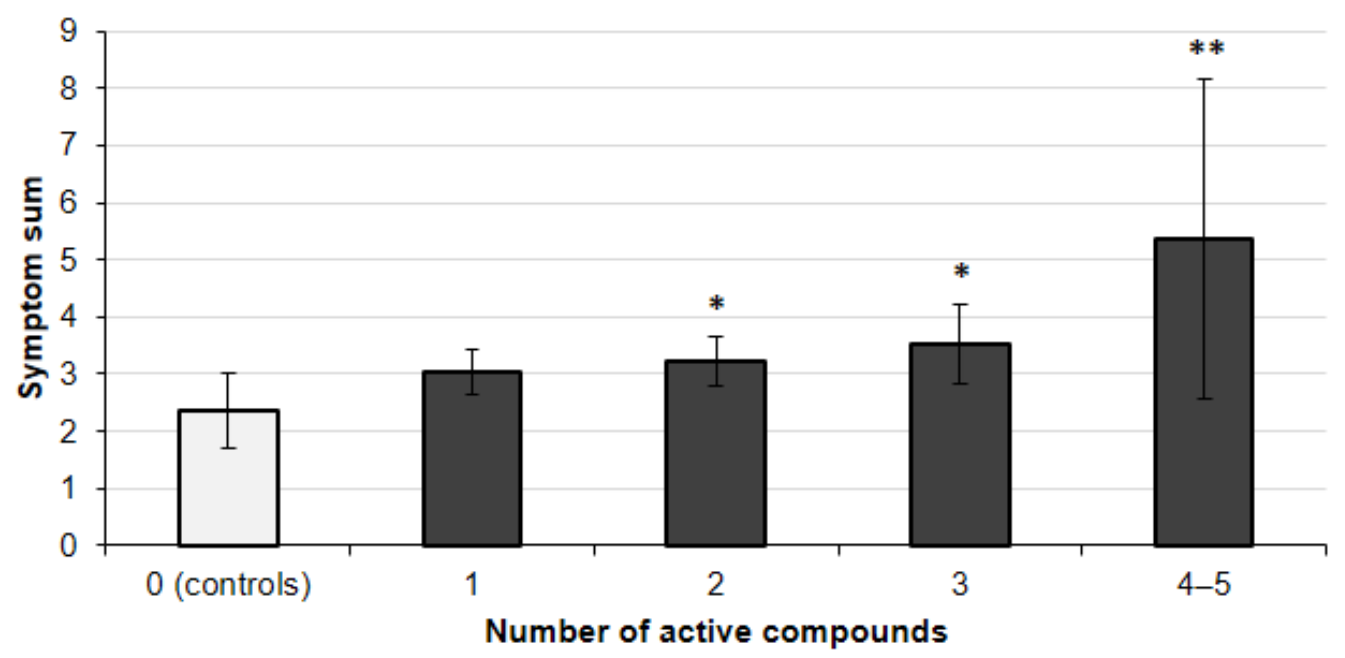

Figure 1

Mean of overall signs score (a) and symptom sum (b) with 95\% confidence intervals related to number of active compounds in glaucoma patients compared to controls *Denotes statistical significance (Mann-Whitney) compared to controls with $p<0.05$ ${ }^{*}$ Denotes statistical significance compared to controls with $p<0.01{ }^{* * *}$ Denotes statistical significance compared to controls with $p<0.001$ 


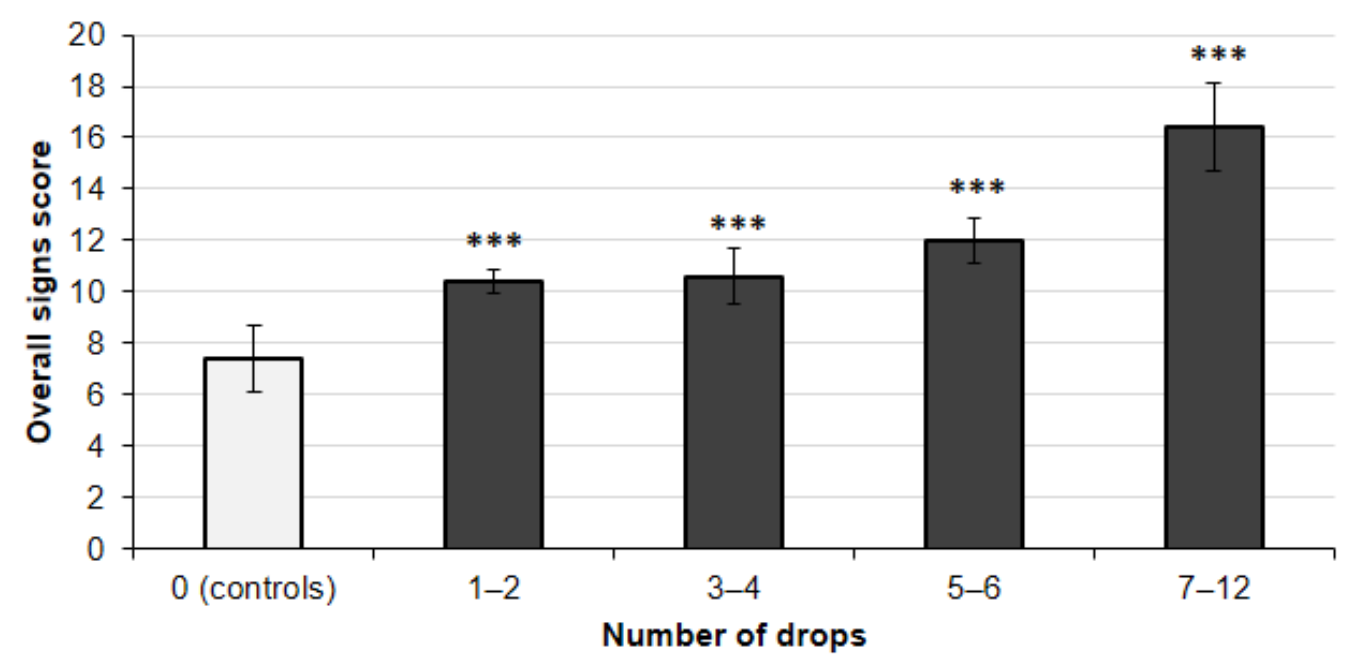

b

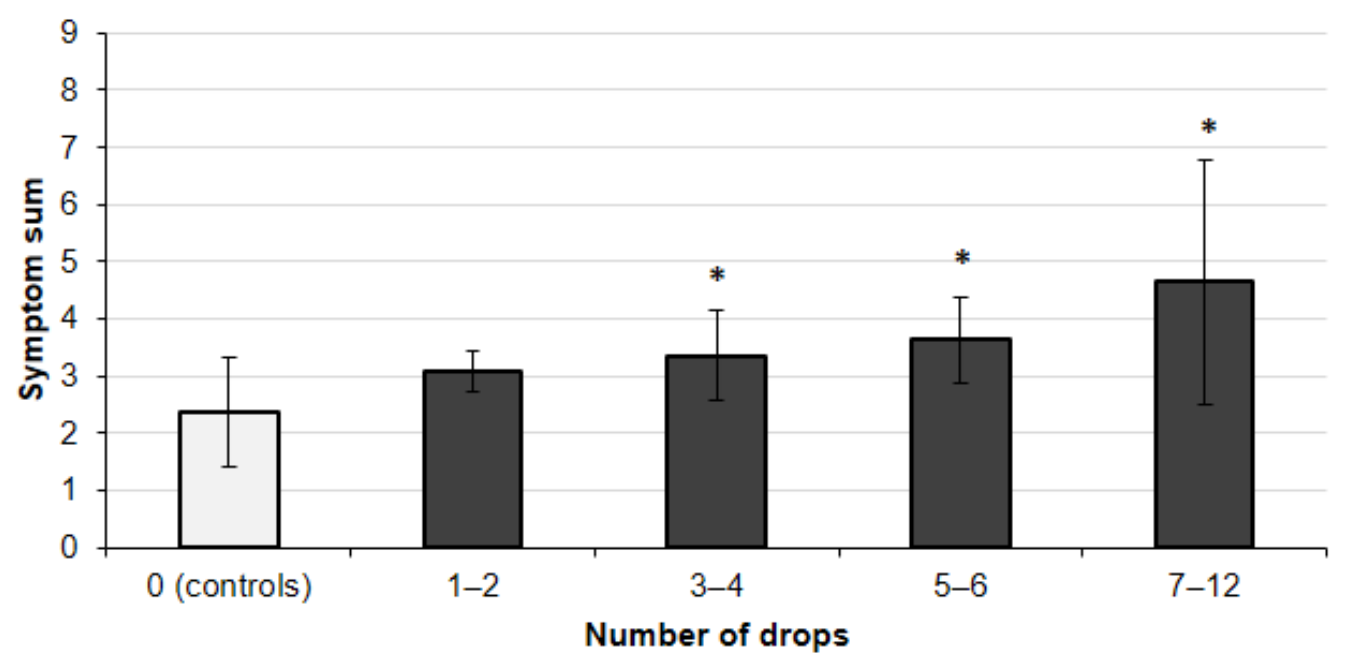

Figure 2

Mean of overall signs score (a) and symptom sum (b) with $95 \%$ confidence intervals related to number of administered eye drops per day among glaucoma patients compared to controls *Denotes statistical significance (Mann-Whitney) compared to controls with $p<0.05 * \star$ Denotes statistical significance compared to controls with $p<0.01 * \star \star$ Denotes statistical significance compared to controls with $\mathrm{p}<0.001$ 